\title{
Evolving American Investing Attitudes: The Hybrid Shift In Mutual Fund Distribution
}

Brian D. Fitzpatrick, Rockhurst University, USA Ethan McWilliams, Rockhurst University, USA David B. Vicknair, Rockhurst University, USA

\begin{abstract}
This paper studies the dramatic evolution in the way American investors choose to invest in the mutual fund industry. The industry's change from direct-to-shareholder model to a third-party distribution model is discussed, as well as the implications for future mutual fund investors.

Ever since the first recorded asset and debt managers arose in the $14^{\text {th }}$ and $15^{\text {th }}$ centuries in Europe, investing has grown into a tug-and-pull type of system that the human mind seems drawn to. The way that Americans choose to invest their money is changing as we enter the $21^{s t}$ century and the new methods and procedures are having a greater impact than many of us realize. In the U.S., trillions of dollars each year are invested in mutual funds, but more and more investors are taking a less-involved route by allowing financial analysts to choose where their money is invested.

In the following pages, we will take a closer look at the mutual fund market and its basic components, the ways that mutual funds have been viewed and traded in the past, and the revolutionary changes that are happening right under our noses that the average American may not even be aware of. With the help of many credible sources, such as the Investment Company Institute, Reflow Investments LLC, and the Financial Planning Journal, the change from direct-toshareholder mutual fund distribution to third-party intermediary distribution will be explained and the effects these changes has on the average investor will be explored.
\end{abstract}

Keywords: Wall Street Wire Houses; Direct-to-Shareholder Model; Mutual Fund Processing; Third-Party Distribution Model; Investment Company Institute; Redemption Fees; and Net Asset Value

\section{INTRODUCTION}

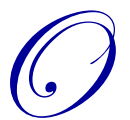

ver the past few decades, there has been a dramatic shift in the way that mutual funds are presented and sold to interested public investors. Until the late 1970s, the only option was to buy and consequently sell shares of a given mutual fund, generally with only one class of shares offered. Most often, an investor bought into a mutual fund by communicating only with the source and dealing with a specific fund manager directly in order to buy shares in a mutual fund. ${ }^{1}$ However, due to many key changes in multiple financial areas, a dynamic and revolutionary change has occurred in normal mutual fund processing. Factors, such as a change in the individual investor's psyche, new concepts and cost structures implemented by the mutual funds themselves, new governmental regulations, and a rapidly increasing percentage of the population interested in investing their money for retirement, have led the majority of investors to entrust a knowledgeable professional with making the final call on investing decisions.

\footnotetext{
${ }^{1}$ Investment Company Institute ${ }^{\circledR}$ Perspective: Vol. 9/No. 3, July 2003, page 1

(C) 2012 The Clute Institute http://www.cluteinstitute.com/
} 
Mutual funds have the distinct ability to offer both diversification of an individual's investments and professional management of those investments. Unlike stocks or bonds which are traded from investor to investor through an organized exchange or market, shares of a mutual fund are purchased from the fund itself, either directly or through the use of an intermediary such as a broker. ${ }^{2}$ Mutual fund shares are unique in that shareholders can redeem their shares by selling them back to the fund at any time; the compensation the investor would receive on the sale is dependent on the fund's current net asset value, or NAV, less any fees or charges that are assessed upon redemption. ${ }^{3}$

Just because mutual funds are professionally managed does not, by any means, result in an absence of risk. As with every investment, there is definitely a risk factor involved regardless of the past performance of a given mutual fund or the track record of the investment advisor overseeing the portfolio. [The term "portfolio" is used here to collectively describe the individual stocks, bonds, etc. that compose the complete repertoire of investments in a mutual fund.] It is paramount to keep in mind that each individual investor has a strategy and end goals that create their desire to invest. Some may look for low-risk historically strong funds in hopes of reaping small gains over lengthy periods of time. Others will look for funds that may seem to be underperforming and buy shares assuming the price will eventually rise. Still others will take on very volatile investments, feeling that the possible reward outweighs the high-risk nature. With all of this in mind, there is not one specific mutual fund (or even type of mutual fund) that is collectively agreed upon to be the top performer. However, there are general advantages and disadvantages that mutual funds carry, as shown in Table $1 .{ }^{4}$

Table 1: Advantages \& Disadvantages of Mutual Funds

\begin{tabular}{|l|l|}
\hline \multicolumn{2}{|c|}{ General Advantages of Mutual Funds } \\
\hline $\begin{array}{l}\text { Professional Management-Professional money managers } \\
\text { research, select, and monitor the performance of the securities } \\
\text { the fund purchases. }\end{array}$ & $\begin{array}{l}\text { Cost Despite Negative Returns-Investors may have to pay } \\
\text { sales charges, annual fees, and other expenses regardless of } \\
\text { how the fund performs. }\end{array}$ \\
\hline $\begin{array}{l}\text { Diversification-Spreading investments across a wide range } \\
\text { of companies and industry sectors can help lower risk if a } \\
\text { company or sector fails. It is easier to achieve diversification } \\
\text { through ownership of a mutual fund rather than owning many } \\
\text { individual stocks or bonds. }\end{array}$ & $\begin{array}{l}\text { Price Uncertainty-With a mutual fund, the price at which } \\
\text { you purchase or redeem shares will depend entirely on the } \\
\text { fund's NAV, which may not include up-to-the-minute price } \\
\text { changes. Some mutual funds may not calculate the NAV until } \\
\text { hours after the redeem order has been placed. }\end{array}$ \\
\hline $\begin{array}{l}\text { Affordability-Mutual funds can accommodate investors who } \\
\text { don't have a lot of money to invest by setting low dollar } \\
\text { amounts for initial purchases. }\end{array}$ & $\begin{array}{l}\text { Lack of Control-Investors typically cannot ascertain the } \\
\text { exact make-up of a fund's portfolio at any given time, nor can } \\
\text { they influence which securities the fund manager buys and } \\
\text { sells or the timing of those trades. }\end{array}$ \\
\hline $\begin{array}{l}\text { Liquidity-Mutual fund investors can readily redeem their } \\
\text { shares at the current Net Asset Value (NAV) at any time. }\end{array}$ & \\
\hline
\end{tabular}

One very unique facet of many mutual funds that should be strongly emphasized is the relatively affordable price tag that they carry. This allows the average investor to acquire a stake in companies with a much wider scope than they would be able to individually afford because stocks of individual companies are sold in bundles and total price can add up very quickly. ${ }^{5}$ For example, a stock that sells at $\$ 10$ per share seems instantly affordable; however, it's likely that this one stock may only sell in bundles of 50 or 100 shares, requiring an investment of $\$ 500-\$ 1,000$ dollars. However, if an investor instead buys $\$ 1,000$ worth of shares in a mutual fund that holds 100 companies, he or she gains some level of ownership (though obviously a small dollar amount) in all 100 of those companies. In short, mutual funds allow investors to more effectively diversify their investment funds.

Of course, as mentioned previously, there are certainly investors who could argue that any one of these general advantages of mutual funds could act in the opposite fashion. For example, diversification could be viewed as counterproductive if one sector performed at an extremely high level and the other portions of the portfolio did not, which would logically dilute the earnings. One could posit that if that sector had been more heavily relied on in the portfolio, the overall performance would have been greater, and that would certainly be true (and, for investors

\footnotetext{
${ }^{2}$ Invest Wisely: An Introduction to Mutual Funds, page 1.

${ }^{3}$ Invest Wisely, 1

${ }^{4}$ Invest Wisely, 3

${ }^{5}$ Funds 101: MSN Money Central
} 
such as those, there are more specified types of mutual funds such as sector funds, whose portfolio would consist of many different companies from the same economic sector). Nevertheless, the assortment above is generally considered accurate for the average investor.

"Mutual funds (are) the dominant investment and savings vehicle in the U.S.", writes Paul Schaeffer, principal author for ReFlow's WhitePaper publication. "Within the mutual fund industry, there is room for every type of investor. An individual can be as involved or uninvolved as he (or she) chooses to be, and that's part of what makes it so attractive. One person may want to pick and choose specifically which industry they believe is going to boom or bust and another wants the luxury of having money invested, but doesn't have the time or desire to be so hands on." 6

\section{MUTUAL FUND DISTRIBUTION CHANNELS}

Mutual funds are offered for sale in five distinct distribution channels. Although some share similar characteristics, each offers its own distinct advantages and disadvantages. The five distribution channels are very well explained in Table 2, taken from Investment Company Institute ${ }^{\circledR}$ Perspective newsletter. ${ }^{7}$

Table 2: Distribution Channels

\begin{tabular}{|c|c|c|c|c|c|}
\hline Channel & $\begin{array}{l}\text { Principal } \\
\text { Investors }\end{array}$ & $\begin{array}{l}\text { Organization } \\
\text { Providing } \\
\text { Transaction } \\
\text { Services } \\
\end{array}$ & $\begin{array}{l}\text { Method of } \\
\text { Conducting } \\
\text { Transactions }\end{array}$ & $\begin{array}{l}\text { Mutual Funds } \\
\text { Offered }\end{array}$ & Investor Services \\
\hline Direct & Individuals & $\begin{array}{l}\text { Mutual Fund } \\
\text { Companies }\end{array}$ & $\begin{array}{l}\text { Orders placed directly } \\
\text { with mutual fund } \\
\text { companies. }\end{array}$ & $\begin{array}{l}\text { Funds of the } \\
\text { fund company } \\
\text { offering the } \\
\text { transactions. }\end{array}$ & $\begin{array}{l}\text { Investment } \\
\text { information }\end{array}$ \\
\hline Advice & Individuals & $\begin{array}{c}\text { Full-service } \\
\text { securities firms, } \\
\text { registered adviser } \\
\text { firms, and insurance } \\
\text { agencies }\end{array}$ & $\begin{array}{l}\text { Orders placed with } \\
\text { reps of firms } \\
\text { providing transaction } \\
\text { services who transmit } \\
\text { to fund companies. }\end{array}$ & $\begin{array}{l}\text { Funds from a } \\
\text { large number of } \\
\text { fund companies. }\end{array}$ & $\begin{array}{l}\text { Investment } \\
\text { information, advice, } \\
\text { ongoing assistance; } \\
\text { access to funds from } \\
\text { different companies } \\
\text { within one account. }\end{array}$ \\
\hline $\begin{array}{l}\text { Retirement } \\
\text { Plan }\end{array}$ & $\begin{array}{l}\text { Participants in } \\
\text { Contribution } \\
\text { Plans }\end{array}$ & $\begin{array}{l}\text { Plan Sponsor or } \\
\text { Employee }\end{array}$ & $\begin{array}{l}\text { Orders placed with } \\
\text { plan administrators } \\
\text { who transmit orders to } \\
\text { fund companies. }\end{array}$ & $\begin{array}{l}\text { Limited number } \\
\text { of funds } \\
\text { selected by plan } \\
\text { sponsor. }\end{array}$ & $\begin{array}{l}\text { Investment } \\
\text { information }\end{array}$ \\
\hline Supermarket & $\begin{array}{l}\text { Individuals and } \\
\text { registered } \\
\text { advisors }\end{array}$ & Discount Brokers & $\begin{array}{l}\text { Orders placed with } \\
\text { discount brokers who } \\
\text { transmit orders to } \\
\text { fund companies. }\end{array}$ & $\begin{array}{l}\text { Funds from a } \\
\text { large number of } \\
\text { fund companies. }\end{array}$ & $\begin{array}{c}\text { Investment } \\
\text { information, access to } \\
\text { funds from different } \\
\text { fund companies within } \\
\text { one account. }\end{array}$ \\
\hline Institutional & $\begin{array}{c}\text { Trusts, } \\
\text { Businesses, } \\
\text { Financial } \\
\text { Institutions, } \\
\text { Endowments }\end{array}$ & $\begin{array}{l}\text { Mutual Fund } \\
\text { Companies }\end{array}$ & $\begin{array}{l}\text { Direct contact with } \\
\text { mutual fund } \\
\text { companies or with } \\
\text { agents of the } \\
\text { companies. } \\
\end{array}$ & $\begin{array}{l}\text { Funds of the } \\
\text { fund company } \\
\text { offering the } \\
\text { transaction. }\end{array}$ & $\begin{array}{l}\text { Investment } \\
\text { information }\end{array}$ \\
\hline
\end{tabular}

As Table 2 shows, the first four investment channels listed primarily serve individual investors and only one deals largely with businesses and financial institutions. This is due, in part, to the large monetary value of investments made by businesses because they most often have more disposable capital at their fingertips than do individual investors. Though the Institutional mutual fund is definitely prevalent today, it has not been as drastic of a shift as the channels that primarily serve individuals. There are four channels that individuals can use to obtain shares in a mutual fund, and each of them serves a purpose and carries risks and rewards of its own.

\footnotetext{
${ }^{6}$ Reflow, LLC; White Paper, November 2009, page 17

${ }^{7}$ ICI Perspective, 4
} 
Direct channel distribution is probably the most traditional and hands on approach to mutual funds out of the four channels available to individual investors. In direct distribution, investors personally choose specific mutual funds that they want to invest in. They take responsibility to carry out transactions directly with the mutual fund company through whatever communication medium they see fit - mail, phone call, e-mail and the internet, or by visiting a local customer service center. In the direct channel, the fund company does not provide investment advice, so the investor must research the funds on their own and trust the decisions that they make. ${ }^{8}$

The fund company does, however, provide ongoing services, such as quarterly statements, record-keeping, and transaction processing, to the shareholder. More and more in the modern era, these services are no longer provided by face-to-face contact or through the mail, but rather through the firm's website. ${ }^{9}$ Because almost all of the costs for direct to shareholder distribution are fixed, there are often higher minimum balances for each investor in comparison to the channels that take advantage of the third party. ${ }^{10}$

The advice channel of mutual fund distribution flaunts a main strength that the direct channel cannot. The principal feature of the advice channel is the provision of investment guidance, assistance, and advice by financial professionals. These professionals include, but are not limited to, full-service brokers at national Wall Street wire houses, independent financial planners and advisers, registered sales representatives at banks or savings institutions, and insurance agents. ${ }^{11}$ The financial adviser that an investor chooses to use can sway based on a multitude of factors such as proximity, personal relationships, ease to contact, past performance, and often most importantly depending on the fees that will be charged for the service.

The retirement plan channel has become increasingly popular since the 1990s when contribution retirement plans, such as the $401(\mathrm{k})$, became one of the primary sources through which investors bought mutual funds. In fact, according to the ICI via Reflow, over half of all mutual fund assets are now held in retirement accounts. ${ }^{12}$ In 2002 , an estimated $\$ 1$ trillion was invested in mutual funds through contribution plans, against a comparably miniscule $\$ 67$ billion in $1990^{13}$. Many 401(k)s and other defined-contribution plans include both an investment made by the individual and a numeric/percentage match contribution made by the employer. For example, if an investor dedicates $5 \%$ of his monthly salary to his $401(\mathrm{k})$ or other retirement savings account, the company he works for may match that $5 \%$. This gives immediate incentive for individuals to really take their retirement savings seriously because they may be earning "free money" from their company.

Though there is a direct investment made by the individual (most often coming directly from their normal salary or wages), retirement plan mutual funds are considered to involve a third party because the employer almost always has an employee whose job it is to manage the company's retirement plan portfolio. This position, generally known as the third-party administrator or TPA, typically handles recordkeeping and other administrative services and assists the employer in selecting investment options to offer to employees. The TPA offers services to the employees of the company that they would not have access to otherwise. Examples of these services are educational seminars about the importance of saving for retirement, investment options, and investment principles ${ }^{14}$. Additionally, having access to a TPA allows employees to have a tangible figurehead with whom to communicate if they have any discrepancies with their retirement plan setup. Many employers will cover the cost of TPA services as an employee benefit, but many choose to defer these fees into the full cost of the plan. For example, a percentage or flat fee for the services may be added right on top of the minimum monthly or yearly contribution to the retirement fund.

Often, financial professionals can be a strong choice for an investor because they can do more than simply act as an intermediary between the investor and the mutual fund. Together, the investor and the professional can

\footnotetext{
${ }^{8}$ ICI Perspective, 4

${ }^{9}$ Invest Wisely, 5

${ }^{10}$ ICI Perspective, 4

${ }^{11}$ ICI Perspective, 4-5

${ }^{12}$ Reflow, 11

${ }^{13}$ ICI Perspective, 5

${ }^{14}$ ICI Perspective, 6 
assess the client's needs and wants and can collaborate to judge the risks and rewards of potential investments. These men and women also maintain all of the shareholder's investment records, send periodic financial information statements, and answer questions that the shareholder may have about their funds or other accounts. The professional can often answer these types of questions much more quickly than if the same information was requested through the direct channel method because he or she handles the account personally and probably knows the exact health of the account at all times.

However, there are, of course, some drawbacks to using a financial professional as the intermediary. Shareholders must compensate these professionals for their services with payment on top of any fees or expenses charged by the mutual fund itself. Fees can be charged in a multitude of ways - one-time sales fees are popular as are annual $12 \mathrm{~b}-1$ fees. In addition, some financial professionals choose to charge their clients a percentage of the assets being managed on a yearly basis - usually between one and two percent. ${ }^{15}$ These fees can often drive potential investors to try the direct method before turning to a professional, though the fees have decreased significantly since $1980 .{ }^{16}$

\section{MUTUAL FUND DISTRIBUTION SHIFT ANALYSIS; WHY THE SHIFT?}

Direct-to-shareholder fund distribution and third-party fund distribution posses both positive and negative features. There have been both government changes in public policy and elected changes within the industry that have driven the shift. However, some analysts posit that the shift in distribution channel may have just as much to do with individual investor characteristics as it does with the characteristics of the industry. Tables 3A and 3B depict just how drastic the change in channel has been since $1980 .{ }^{17}$

Table 3A: Share of Mutual Fund Assets by Distribution Channel, 1980 (Percentage)

\begin{tabular}{|l|c|}
\hline Type & Percent \\
\hline Direct & 56 \\
\hline Advice & 21 \\
\hline Retirement Plan & 7 \\
\hline Supermarket & 4 \\
\hline Institutional & 12 \\
\hline
\end{tabular}

Table 3B: Share of Mutual Fund Assets by Distribution Channel, 2007 (Percentage)

\begin{tabular}{|l|c|}
\hline Type & Percent \\
\hline Direct & 55 \\
\hline Advice & 12 \\
\hline Retirement Plan & 16 \\
\hline Supermarket & 5 \\
\hline Institutional & 13 \\
\hline
\end{tabular}

First, let's take a look at the changes that have occurred within the industry in the last 30 or so years. The first major change got jump started by the SEC in 1980 when it adopted Rule 12b-1. Prior to this implementation, the only way investors could compensate their financial advisers for assistance was through front-end sales loads. A front-end sales load is "an upfront sales charge investors pay when they purchase fund shares, generally used by the fund to compensate brokers. ${ }^{18}$ This made the initial act of hiring an advisor unattainable for many low-profile investors because the startup cost was simply too steep.

After the implementation of Rule 12b-1 under the Investment Company Act of 1940, investors have enjoyed the ability to compensate their advisers in a variety of different ways. For example, the so-called " $12 \mathrm{~b}-1$ fee" is paid monthly or yearly based as a percentage of the assets of the mutual fund owned by the investor rather than having to pay a fixed amount up front. The recurring fee is used not only to compensate financial advisers for

\footnotetext{
${ }^{15}$ Invest Wisely, 7-8

${ }^{16}$ ICI Perspective, 5

${ }^{17}$ Financial Planning Journal, April-June 2008, page 2

${ }^{18}$ Invest Wisely, 15
}

(C) 2012 The Clute Institute http://www.cluteinstitute.com/ 
their initial services but also to pay for ongoing shareholder services, payments to fund underwriters, and for promotion and advertising of the company, even though 12-b1 was originally designed to strictly pay for marketing and advertising expenses. Table 4 shows the percentage of $12 \mathrm{~b}-1$ fees used for each, according to an ICI survey conducted in 2004. ${ }^{19}$

Table 4: Use of 12b-1 Fees (Percentage)

\begin{tabular}{|l|c|}
\hline Type & Percent \\
\hline Ongoing Shareholder Services & 52 \\
\hline Compensation to Financial Advisers for Initial Assistance & 40 \\
\hline Promotion and Advertising & 2 \\
\hline Payments to Fund Underwriters & 6 \\
\hline
\end{tabular}

In addition to the 12b-1 fees impact, the industry has also been greatly affected by the volatility of asset flows. Monthly gross flows have historically hovered right around 4 to 5 percent, but have recently skyrocketed to just over 9 percent. ${ }^{20}$ This means that at any given month, billions of dollars worth of mutual fund shares are in the process of changing hands. It's interesting to note as well that this fluctuation began in 2006, well before our current financial crisis struck in the fall of 2008. According to research conducted by the ICI, rising asset flows are not a cyclical or temporary phenomenon, but one that is likely here to stay, at least for the next decade.

Market volatility has encouraged investors to switch their mutual fund strategies. Very few investors are currently implementing the "buy-and-hold" type strategy for their mutual funds because they either jump ship when the going is tough or they take their earnings and run when the fund increases slightly. There are also very low costs (or sometimes even none) associated with switching mutual funds, so there is no penalty incurred for being impulsive. In fact, $86 \%$ of new asset flows into mutual funds over the past ten years have been to no-load funds, leading to the average investor's unwillingness to hold their funds over periods of both increases and decreases. ${ }^{21}$ The Figure 1 shows average holding patterns for mutual funds since $2002 .^{22}$

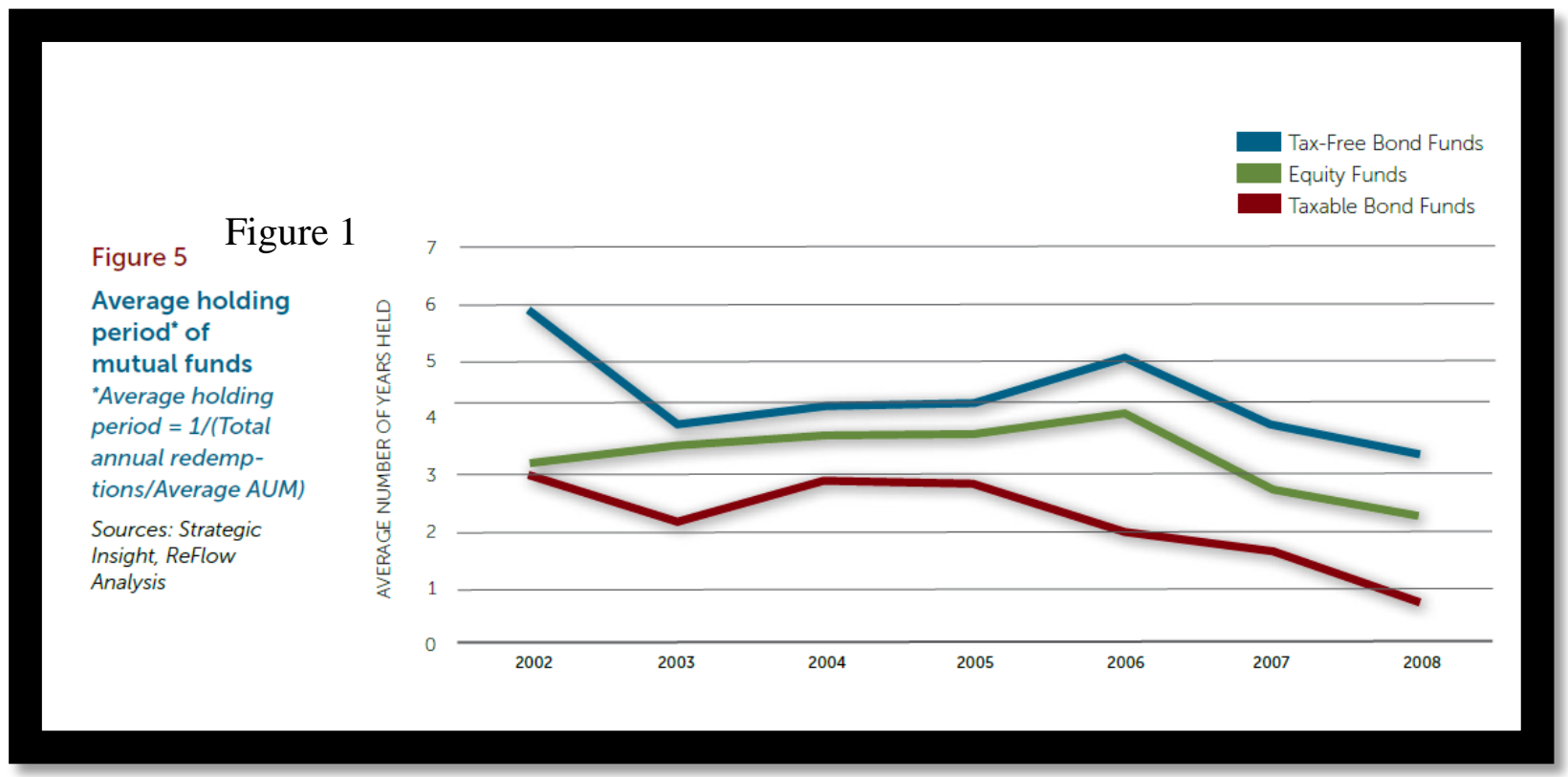

Figure 1

${ }^{19}$ ICI Fundaments Vol. 14/No. 2, February 2005, page 2

${ }^{20}$ Reflow, 2

${ }^{21}$ Reflow, 8

${ }^{22}$ Reflow, 9 
The volatility of flows has a great deal of impact on the performance of the mutual fund market. A great deal of subscriptions and redemptions of shares creates such a liquid market that fund managers may make decisions they would not characteristically make, which can undercut the value of the funds as a whole. The high flow market "drives trading to distort investment strategies, imposes higher transaction costs (because more trades are taking place), distracts portfolio managers and traders from carrying out their desired strategy, and generates unwanted capital gain distributions." 23

Logically, it seems that with higher transaction costs, flow-driven trading would slow down rather than increase. Research studies have shown that for each dollar of strategy-driven trading, this increases portfolio value an estimated $\$ 0.71$; in contrast, each dollar of flow-driven trading lowers the value and returns by $\$ 0.86$. Flow driven trading has been estimated to account for 30 to 40 percent of all trading, leading to the assumption that investors and advisers alike would desire to get back to strategy-driven trading, but the transition is obviously not as easy as it sounds. ${ }^{24}$

One major social factor that has had a giant impact on mutual fund transactions over the past decade is that the members of the "baby boomer" generation have been aging and are beginning to reach retirement age. It is estimated that in the next 40 years, the number of living Americans over the age of 65 will double. Baby Boomers have historically traded at both a higher percentage than other age groups. According to U.S. Census Bureau data via Reflow, 56\% of Americans aged 45-54 and over 50\% of Americans aged 55-64 hold shares in mutual funds, versus only about one-third of those aged 35-44. Because they have more money invested in mutual funds and retirement accounts, there is no question that the increase in trading activity will continue throughout their retirement years as they pull the money out of their retirement funds.

On the other hand, the change in public policy has been significant, beginning with the passage of ERISA (Employee Retirement Income Security Act) in $1974 .{ }^{25}$ Prior to ERISA, pension plans offered by individual companies were often felt to be misrepresented and abused and many thought employers were often not being thorough when explaining the regulations for their pension plans. ERISA set minimum standards for pension plans for companies in the private industry sector, as well as "(ERISA) specifies when an employee must be allowed to become a participant, how long they have to work before they have a non-forfeitable interest in their pension, how long a participant can be away from their job before it might affect their benefit, and whether their spouse has a right to part of their pension in the event of their death. ${ }^{26,}$

ERISA was shortly followed by the addition of section $401(\mathrm{k})$ to the Internal Revenue Code. ${ }^{27}$ After ERISA was enacted, many companies felt they could not meet the required minimums and stopped offering pension plans as an employee benefit. As a result, retirement became almost entirely the responsibility of the individual. In 1981, the IRS made a revision of the definition of "taxable income", leading to the ability of employers to taxexempt contributions to 401(k) savings plans from taxable incomes. This has led not only to a rise in the number of DC plans (as discussed earlier), but also to an increase in the volume of dollars held in those plans. The introduction of regular paycheck withdrawals, employer retirement match programs, and rollover accounts allows investors to make decisions early in their professional careers that will impact the lifestyle they are able to live 40 or more years into the future.

In August 2006, President Bush signed into law the Pension Protection Act of 2006 (PPA). This law was passed with strong bipartisan support because of economic research studies which showed that many individuals were not saving enough for retirement. In addition, research showed that individuals are largely passive in their investing for retirement behaviors and that many people simply don't understand the need to start saving early in

\footnotetext{
${ }^{23}$ Reflow, 2

${ }^{24}$ Reflow, 3

${ }^{25}$ U.S. Department of Labor, History of EBSA and ERISA.

${ }^{26}$ U.S. Department of Labor, What is ERISA?

${ }^{27}$ Public Policy and Savings for Retirement: the "Autosave" Features of the Pension Protection Act of 2006; Beshears, Choi, Laibson, Madrian, Weller, page 3
}

(C) 2012 The Clute Institute http://www.cluteinstitute.com/ 
their careers. The PPA included "autosave features", which are recommendations for employer adoption that lead individuals to begin contributing to their defined contribution savings plans. Among these features $\operatorname{are}^{28}$ :

- Automatic Enrollment: Employees are automatically enrolled in a savings plan at a default contribution rate and default asset allocation unless they explicitly choose to opt out.

- Employer Contribution: The employer makes a contribution to employee accounts either on a noncontingent basis (independent of whether employees contribute anything) or as a match on employee contribution.

- $\quad$ Contribution Escalation: Participant contributions to the savings plan automatically increase over time.

- $\quad$ Qualified Default Investment Alternative (QDIA): Contributions are defaulted into a diversified portfolio that includes exposure to both equity and fixed income assets.

\section{COST IMPLICATIONS}

Changes in government policy, adaptations and new concepts in the industry, and a changing investor demographic have all strongly contributed to the change in mutual fund distribution. There is a bottom line, though, that often ends up driving the decision-making process in this industry - what will be the monetary results of such drastic industry changes? Are the opinions of professional financial analysts really valuable enough to justify paying for their services? It seems as if fees are rising and value is dropping as a result of flow-driven trading. So what is the upside at this point to owning shares in mutual funds?

The fees that a fund charges are almost always derived as a percentage of the initial investment being made. As we've already touched on, a front-end sales load is a fee that is paid to the broker at the initial purchase and reduces the amount of the investment. For example, a $\$ 1,000$ investment with a fund that carries a 5\% sales load will result in a $\$ 50$ commission for the broker and a $\$ 950$ investment into the fund.

Some funds will choose to carry a back-end sales load, also known as deferred sales charge. A back-end sales load is a fee paid to the broker when the shares are sold and is usually exercised when the fund is predicted to perform favorably. Using the same $\$ 1,000$ example, if the fund performs well and increases $20 \%$, the investment would then be worth $\$ 1,200$. In turn, the 5\% sales load would then earn the broker $\$ 60$ and the investor would collect the difference. Interestingly, back-end sales loads usually have a diminishing percentage based on how long the investor holds the fund's shares; often after a long-run, the fee is waived as a benefit for the loyalty to the broker and the fund.

Purchase fees, redemption fees, exchange fees, and account fees are also common activity-driven charges that can be assessed to investors. These fees are almost always paid to the fund rather than the broker and are typically used to defray costs associated with redemption of the shares. Account fees can be imposed on investors whose accounts fall below a certain dollar amount or have inactive accounts for a certain length of time. In short, there are always fees past the initial investment, whether the investor is an active trader or a buy-and-hold investor.

In recent history, a large push has been made by many funds to move toward a strategy that seemingly seems perfect, which is called the "no-load" approach. For the uninformed investor, this can seem like a great deal because it cuts out the initial expense to the broker or the percentage takeaway when the shares are redeemed. Nevertheless, no-load funds also have operating expenses and their brokers will undoubtedly still get paid in some fashion. Though there are regulations placed on purchase fees, redemption fees, exchange fees, and account fees, the amount that a no-load investor may pay for those services may end up costing more traditional approaches.

It's impossible for anyone participating in a fair market to know exactly what is going to happen with any given mutual fund. However, defenders of the inefficient market hypothesis posit that with close study and observation, an investor can consistently pick the correct options for his or her investment strategy. Based on the loads and fees presented at the beginning of a shareholder/broker negotiation, wise investors can sense as to which

\footnotetext{
${ }^{28}$ Beshears, Choi, Laibson, Madrian, Weller, 5 
funds will bust, which will ultimately perform well, and which funds will not be prudent investments based on the given fees, and which can be exploited for wealth maximization.

\section{CONCLUSION}

Although we believe that each of us has the ability to choose, negotiate, and reap the rewards for making our own personal decisions regarding the mutual fund market, the shift from direct-to-shareholder distribution to third-party distribution of mutual funds is a good shift for both the retail investor and the industry as a whole. The cost of a third-party financial analyst with whom to discuss mutual fund investment strategies can be worth the multitude of services he or she provides. The busy lives of investors often leave them without the time and attention that investments absolutely rely on.

For starters, it has created numerous jobs for Americans because of the common desire to have professional guidance and help in choosing the best funds to fit each personal strategy. Building on that, investors can have a greater feeling of confidence in the decisions they make when consulting with an analyst who builds a career around giving financial guidance and, in turn, that will lead a greater percentage of the American population to investing money. Because of the decrease in confidence regarding Social Security benefits and other government aid programs across the country, the public in greater numbers have begun to take matters into their own hands when it comes to investing for retirement.

These, along with a multitude of other factors listed throughout the paper, have led to demand for thirdparty intermediaries to skyrocket. With that said, however, we do not believe that the mutual fund market will ever get to a point where it is distributed $100 \%$ by third-party professionals, and we believe that this is ultimately beneficial for investors. When too much power and influence over such a monetarily large industry is given to a relatively small group of individuals, there can often be negative and unforeseen results that come from it. We also believe there are some individual investors who simply have a knack for making these types of decisions on their own and who will not need an advisor to aid them. Regardless, we are thoroughly intrigued to witness what the future will hold for this industry, and hopefully new changes to the industry will benefit the majority of investors.

\section{AUTHOR INFORMATION}

Brian D. Fitzpatrick, Ph.D., received an AA degree with an emphasis in English from Meramec Community College in 1973. He graduated Magna Cum Laude with a BS degree in Psychology from Southeast Missouri State University in 1975, and a MBA with an emphasis in Finance in 1980, and a Ph.D. in Business Administration with a major in Finance with a concentration in Investments in 1991 from Saint Louis University. Brian has spent ten years in the investment field including positions with two major Wall Street wire houses. Currently he is a tenured full Professor of Finance at Rockhurst University. Dr. Fitzpatrick has published in ten different fields: Accounting, Economics, Experimental Psychology, International Finance, Corporate Finance, Investments, Real Estate, Management (Entrepreneurship), Information Technology and Poetry. E-mail: brian.fitzpatrick@rockhurst.edu (Corresponding author)

Ethan McWilliams is originally from Lincoln, Nebraska and earned a BSBA in Accounting/Finance at Rockhurst University in Kansas City, Missouri. As an undergraduate, Ethan held leadership positions in Tau Kappa Epsilon Fraternity, Delta Sigma Pi Professional Business Fraternity, and Rockhurst University Inter-fraternity Council. He is currently working towards his MBA with a Finance concentration at Rockhurst University. Ethan is employed full-time for the Federal Department of Labor in Kansas City. Ethan hopes to pursue a career in Investments or Financial Advising after completing his MBA requirements.

David Vicknair earned his DBA from the University of Tennessee, a MS from the University of Southern Mississippi and a BBA from Millsaps College. He has worked at Rockhurst University for 17 years as an Associate Professor of Accounting. David's teaching focus includes International Accounting, Advanced Accounting, Foundations of Managerial Accounting, Foundations of Finance and Financial Accounting, to name a few. He has authored or coauthored articles in accounting, finance and healthcare; some of which have appeared in leading education journals in those disciplines. E-mail: david.vicknair@ rockhurst.edu 


\section{REFERENCES}

1. $\quad$ "An Overview of Mutual Funds." Morningstar. Web. 08 May 2011. www.morningstar.com/investingclassroom

2. Beshears, John, James J. Choi, David Laibson, Brigitte C. Madrian, and Brian Weller. Public Policy and Saving for Retirement: The "Autosave" Features of the Pension Protection Act of 2006. Rep. Harvard University. Web. 08 May 2011.

http://www.economics.harvard.edu/faculty/laibson/files/Better\%20living\%20080216.pdf

3. $\quad$ "History of EBSA and ERISA." The U.S. Department of Labor Home Page. Web. 08 May 2011. http://www.dol.gov/ebsa/aboutebsa/history.html

4. $\quad$ "How Mutual Funds Use 12b-1 Fees." Investment Company Institute® Fundamentals 14 (5 Feb. 2005). Print.

5. $\quad$ "Invest Wisely: An Introduction to Mutual Funds." U.S. Securities and Exchange Commission (Home Page). 10 Jan. 2003. Web. 08 May 2011. http://www.sec.gov/investor/pubs/inwsmf.htm

6. Reid, B. K., and Rea, J. D. (2003, July). Mutual fund distribution channels and distribution costs. Investment Company Institute ${ }^{\circledR}$ Perspective 9.

7. Schaeffer, Paul, and Brigitte LeBlanc. "How Mutual Fund Distribution Is Changing--and What It Means for Performance." Comp. Steven Unzicker. White Paper. Reflow, LLC. (Nov. 2009). Print.

8. $\quad$ "What Is ERISA?" The U.S. Department of Labor Home Page. Web. 08 May 2011. http://www.dol.gov/ebsa/compliance assistance ERISA.htm 